\title{
Review, impact of land use/cover change on soil erosion in the Lake Tana Basin, Upper Blue Nile, Ethiopia
}

\author{
Alemsha Bogale ${ }^{1}$ \\ Received: 29 March 2020 / Accepted: 28 October 2020 / Published online: 7 November 2020 \\ (c) The Author(s) 2020
}

\begin{abstract}
Lake Tana Basin is located in upper Blue Nile Basin which is comprises a total area of $15,096 \mathrm{~km}^{2}$ of which $3063 \mathrm{~km}^{2}$ is covered by the Lake which is the source of Blue Nile river. Lake Tana Basin and Blue Nile River provide various benefits also for downstream countries. The basin is highly degraded by different natural and manmade problems and it influence both Ethiopia and downstream countries. The main cause of basin degradation is inappropriate LULC. Huge area of cultivated land using without suitable management is the major basin problem. It is due to insure food security coming from unprecedented population growth rate. Forested land has encouraged the infiltration capacity and permeability of the land. It helps to increase the recharge capacity contribute to base flow whereas it is vice versa for cultivated land which is quick overland flow and significant soil erosion have observed. Besides, the soil erosion from agricultural land is the main source of nutrient enters to the lake which is the cause for eutrophication. To combat such problems both up and downstream countries should discuss together and design and implement appropriate basin management strategies to sustain the biodiversity and hydrological system of the basin.
\end{abstract}

Keywords Lake Tana $\cdot$ LULC $\cdot$ Soil erosion $\cdot$ Lake Tana Basin

\section{Introduction}

Ethiopia, mostly dominated by mountainoustopography is the source of water for east Africa which is from rainfallrunoff process (Derib et al. 2009). Understanding rainfallrunoff process is essential to control problems and improve productivity of the watershed. Erosion is the major problems in the basin and it is high in early period of the wet season, and sediment concentration is frequently recorded before peaks of discharge is observed in a given rainfall season (Steenhuis et al. 2009).

In the Lake Tana Basin, effective utilization of the land and water resource is needed to improve the livelihood of the basin. Both natural and manmade activities are significantly affected existed natural resources of the basin (Setegn et al. 2009). Hydrological process research in the watershed is a vital to identify and provide solutions to save the critical degradation of soil and water resources in the

Alemsha Bogale

galemsha35@gmail.com

1 Department of Water Technology, Bahir Dar Polytechnic College, Bahir Dar, Ethiopia catchment (Easton et al. 2010; Setegn et al. 2008). The lack of resources used to researching problems on the watershed are challenging to overcome significantly the research and development in the area (Setegn et al. 2009). To solve the existing soil erosion problems there is a need to identify the most erosion sensitive areas in the region, so that effective conservation measures can be taken.

\section{Area description}

Lake Tana is largest lake in Ethiopia and the third largest in Nile Basin is located in upper Blue Nile Basin, Ethiopia. It is stretched between $10.95^{\circ}$ and $12.78^{\circ} \mathrm{N}$ latitude and $36.89^{\circ}$ and $38.25^{\circ} \mathrm{E}$ longitude with a drainage area of about $15,096 \mathrm{~km}^{2}$ of which, $3063 \mathrm{~km}^{2}$ of land is covered with Lake Tana (Fig. 1). The climate of the Lake Tana sub-basin is dominated by tropical highland monsoon with most of its rainfall occurring between June and September. The lake is receiving more than $93 \%$ of flow from four major rivers which are Gilgel Abay, Gumara, Ribb, and Megech (Setegn 2010). Gilgel Abay is the largest contributing river with a catchment area of $3822 \mathrm{~km}^{2}$. The south-east part of the watershed is high (3524 masl) in elevation and it becomes 


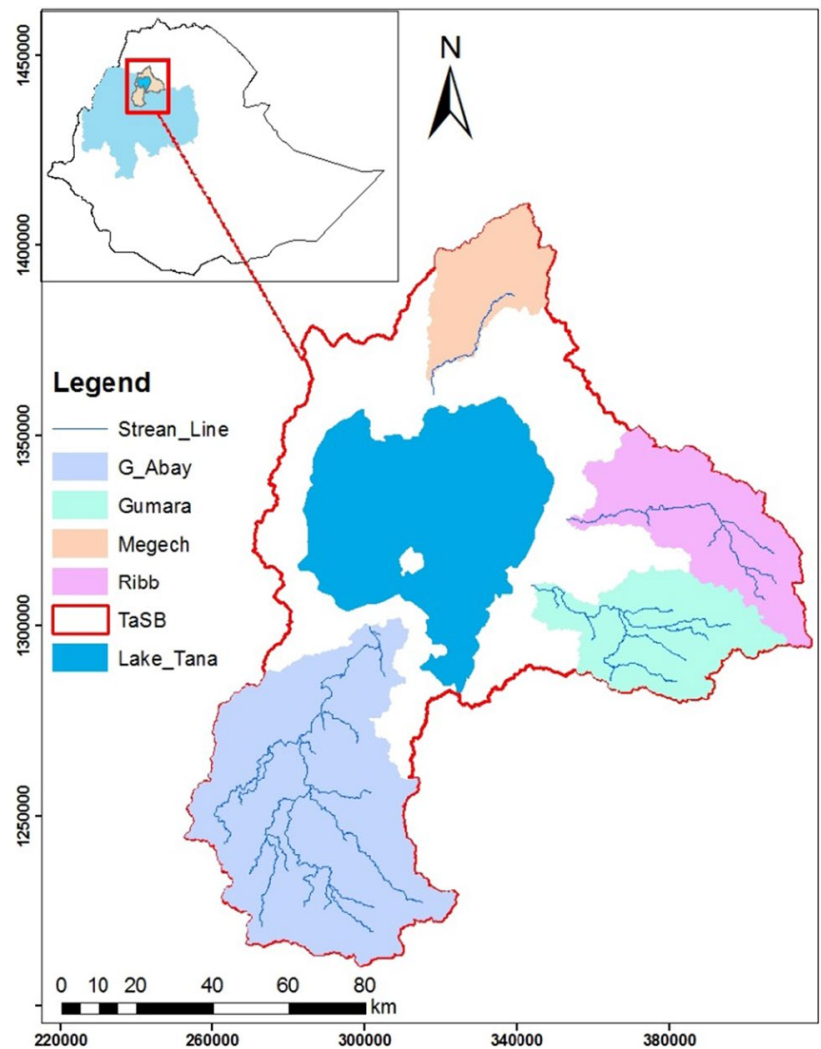

Fig. 1 Location map of review area

decrease to the north which is the river mouth of the lake (1790 masl). Whereas, Gumara and Rib watersheds are adjacent rivers which are flows from east to west contributing to the lake. The elevation ranges from $1784 \mathrm{~m}$ to $4109 \mathrm{~m}$ above mean sea level (amsl). The contributing area of the watersheds is $2960 \mathrm{~km}^{2}$. Another tributary watershed is Megech which is contributing $844 \mathrm{~km}^{2}$ area of land. The watershed is elevation difference from 1787 to 2972 masl. All watersheds characterized as a mountainous and terrain with steep slopes at the upper part of the basin and undulating topography with gentle slope from the downstream part of the watershed is the common character of all watersheds. Blue Nile River is the only outlet of the lake which is the source of the River.

\section{Factors affecting soil erosion}

Inappropriate land use and management system with lack of soil and water conservation implementation have significant to land degradation problem in Ethiopia. Ethiopia losses $\$ 1.9$ billion due to soil erosion between 1985 and 2010. To tackle this problem, Ethiopian government with funding organization takes immediate soil and water conservation implementation (Setegn et al. 2009).
Understanding soil erosion factors are significant to formulate effective soil and water conservation structure. The four major factors discussed below are erosivity of rain, erodibility of the soil, topography and land cover (Mekonnen and Melesse 2011).

The amount, duration and intensity of rainfall are important elements in soil erosion (Hurni 1985b; Lal 1984; Morgan and Erosion 2005; Wischmeier and Smith 1978). Soil erodibility is the capacity of soil to transport and detachment. It is a function of Soil texture, structure, organic matter content and permeability (Renard 1997; Wischmeier and Smith 1978). It determines the soil erosion vulnerability (Lal 1984; Morgan and Erosion 2005).

Land topography is another important consideration to understand rate of soil erosion (Wischmeier and Smith 1978). When the length and steepness of the land increase the soil erosion will increase due to increasing the volume of runoff and gathering speed and energy of runoff (Wischmeier and Smith 1978).

Land cover has potential to change watershed characters such as infiltration capacity of the soil, intercepting agent of rainfall, reduce rainfall and runoff energy by improving rainfall erosivity index, improve soil erodibility factor by increasing cohesive or bonding character of soil type which are affect soil erosion vulnerability. According to Hurni (1985a, b) study in Ethiopia, soil erosion in bare land was higher than other land covered by different use. The average rate of soil erosion from bare land is 70 ton $\mathrm{ha}^{-1} \mathrm{yr}^{-1}$ whereas erosion rate from different land covers was between 0 and 42 ton $\mathrm{ha}^{-1} \mathrm{yr}^{-1}$ (Hurni 1985b).

Soil erosion increases with increasing runoff and where soil depth is shallow and heterogeneous (Easton et al. 2010; Mekonnen and Melesse 2011). Lake Tana sub-basin, one of the major basins of the Blue Nile is predicted to have some of the highest sediment yields in the basin, 15 as high as 200 ton $\mathrm{ha}^{-1}$ resulting from cultivation onthe steep slopes, and the relatively high runoff losses that prevail in the region (Easton et al. 2010). Easton et al. (2010) (Mekonnen and Melesse 2011) reported that, cultivated land with steep slope next to grazing land in addition to saturated soil is aggravating soil erosion.

\section{Effects of land use land cover on soil erosion}

Watershed characters and climate change are significant to alter the hydrological process (Fohrer et al. 2001; Huang and Zhang 2004; Laurance 1998; Richey et al. 1989; Schulze 2000; Tu 2009; van Roosmalen et al. 2009; Zhang et al. 2001). As Ethiopia dominated by mountainous topography, high runoff was observed due to steep slope (Derib et al. 2009), and thus, investigating the rainfall-runoff processes is critical to controlling erosion (Easton et al. 2010). Runoff 
losses from upland area become decrease with decreasing drainage basin and thus, increase base flow. It is due to the variation of saturation fraction depending on the drainage area (Easton et al. 2010).

Studies on effect of land use land cover change on hydrological regime as well as soil erosion are not enough (Andréassian et al. 2004; Bosch and Hewlett 1982; Cosandey et al. 2005). Researchers work on effect of land cover changes on hydrological regimes on experimental watershed of small scale $\left(<1 \mathrm{~km}^{2}\right)$ (Bosch and Hewlett 1982; Guillemette et al. 2005; Iroumé et al. 2005; Lavabre et al. 1993; Troendle and King 1987). However, studies in large-scale level $\left(>1000 \mathrm{~km}^{2}\right)$ are a key to design effective soil and water resource management system. So the impact of any disturbance will be minimal when catchments are of regional or larger scale. The dynamic of land use land cover is primary cause to altering the watershed hydrology (Chakilu and Moges 2017).

Land use and land cover of the catchment play a significant role to soil erosion than other catchment characters (Halefom et al. 2019a). Study by Abebe and Minale (2017); (Ayalew and Angelidis 2019) estimated the land use/cover change between 1986 and 2013. In the years between 1986 and 2013, most parts of the watershed covered by forest and grassland were changed to cultivated and settlement. The cover size of the cultivated land was nearly doubled between 1986 and 2013 which was 19\% and 32\%, respectively, whereas settlement was increased significantly from $0.3 \%$ to $19 \%$ (Abebe and Minale 2017). It is the reason why the runoff and erosion increase time to time.

\section{Hydrological regime and land use/cover relation of the basin}

Influential LULC changes were reviewed in different articles. Agricultural land is highly accelerated with time whereas shrub and grassland also reduced simultaneously concluding that the demand for agricultural lands has increased. These LULC change is significantly changed hydrological regime of the watershed. Many studies suggested that significant change of rainfall and stream flow was observed and they conclude that soil erosion is becoming serious issue due to such hydrological change. Rainfall in general has decreasing but it increase in wet season whereas it has decreasing in dry season. In the same manner, the mean annual flow has significantly reduced. Contrary to decrease in low and annual flow, high flow index has increased. Obviously high flow was occurred in wet season (Rientjes et al. 2011). It is likely due to change of land cover and seasonal and annual change of rainfall distribution in the catchment. In terms of land cover, huge area of forest land is converting to agricultural land. Forested land has potential to conserve rainfall and increase infiltration capacity of the surface to encourage subsurface water availability whereas deforestation and land degradation process are susceptible to overland flow and reduce infiltration and recharge flux. This consequently results in quicker runoff responses were flow rates increase and we presume that this partly causes the increase in the high flow index and aggravate soil erosion.

\section{Land use/cover change and hydrological condition of Gilgel Abbay catchment}

Studies by Minale (2013) reported that significant land use land cover change was observed. Most of the watershed covered by forest was changed to cultivated land. In this study, 9328 ha $(1.2 \%)$ of land was covered by the forest in 1973 whereas only 2581 ha $(0.3 \%)$ was covered. In the same line, results of the supervised land cover classification analysis indicated that $20.6 \%$ and $9.3 \%$ of the catchment area was covered by grass land in 1973 and 2008, respectively. It indicates that, the catchment areas were reduced from forest

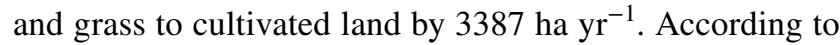
Minale (2013) during the last 35 years, cultivated land was increased from $26.1 \%$ to $41.2 \%$ between 1973 and 2008. The forest, grass and shrub land quickly changed to agricultural land. LULC change (to agricultural) becomes highly accelerated through time (Rientjes et al. 2011). These significant changes in forest and grass land were mainly due to expansion of agricultural land because of unexpected population growth. In the Gilgel Abbay, upland area of the watershed is not sensitive to gully erosion which is the most critical form of soil erosion and sheet and rill erosion are mostly common in this part of the watershed. Stream power index is powerful indicator of gully susceptible area. In large catchment with steep slope, volume and velocity of runoff generated from upslope area will increase. Hence SPI and gully erosion risk becoming increase. Gullies were observed in saturated bottomlands where the most important erosion prone parts of the watershed (Mhiret et al. 2019). The SPI was in the range of 2-16 of which gully potential area where the SPI $>7$ (Mhiret et al. 2019).

\section{Land use/cover change and hydrological condition of Gumara catchment}

Studies on hydrological characteristics of the watershed are basic to tackle the hydrology problems. Absence of accurate data is hampers to conduct such studies. Land use land cover of the watershed is interesting character to explain the hydrological process of the watershed. The extent and rate of land use/cover change between 1973 and 2013 were studied by Chakilu and Moges (2017). Chakilu and Moges (2017); 
(Wubie et al. 2016) reported that significant change of other land use (grass, bush and forestland) to cultivated land was observed. It is in order to meet food demand following population increase. In this point, the forest, bush and grassland were changed to cultivated land. Only $479.36 \mathrm{~km}^{2}$ (37.7\%) of land was covered by cultivated land in 1973 whereas it was about $961 \mathrm{~km}^{2}(75.6 \%)$ in 2013. The annual change of the watershed from other land use to cultivated land was 1204 ha yr $^{-1}$ (Chakilu and Moges 2017).

\section{Land use/cover change and hydrological condition of Ribb catchment}

The largest portion of Ribb watershed was covered by cultivated land (61.3\%) followed by grass land (22.8\%) in 2014 which has significant effect on soil erosion (Estifanos 2014). Whereas studies by Moges and Bhat (2018) reported that about $88 \%$ of land was covered by cultivated land and only $6 \%$ was for grass land in 2016. We observed significance difference of land use/class classification result between different researchers. It is due to LULC maps generated from satellite images always contain some sort of errors originated from several sources, such as classification techniques and methods of image acquisition. As a result, post classification refinement is needed to improve classification accuracy and reduce errors (Butt et al. 2015) and increase the quality of the information. Potential annual soil loss of Ribb micro-watersheds ranges 10.93-95.5 ton $\mathrm{ha}^{-1} \mathrm{yr}^{-1}$ which is agreed with the annual soil loss of the highlands of Ethiopia (16-300 ton $\mathrm{ha}^{-1} \mathrm{yr}^{-1}$ ). When it is compared to soil loss of the neighboring Gumera watershed ranging from 11 to 22 ton $\mathrm{ha}^{-1} \mathrm{yr}^{-1}$, it is very large value. The mean annual soil loss rate of the whole study area is 39.8 ton $\mathrm{ha}^{-1} \mathrm{yr}^{-1}$; which is much greater than the tolerable level of 10 ton ha $^{-1} \mathrm{yr}^{-1}$ (Estifanos 2014; Hurni 1983). The annual soil loss of the highlands of Ethiopia ranges from 16 to 300 ton $\mathrm{ha}^{-1} \mathrm{yr}^{-1}$, of pasture, ranges and cultivated fields throughout Ethiopia (Steenhuis et al. 2009). The study by Estifanos (2014) was proved within the findings of FAO. When we compare this result with the predicted annual soil loss rate in Lake Tana Basin which is $>60$ ton $\mathrm{ha}^{-1} \mathrm{yr}^{-1}$ in rugged topographies and it decreases up to 15 ton $\mathrm{ha}^{-1} \mathrm{yr}^{-1}$ on the area with better catchments characteristics (Yitaferu 2007). Ribb becomes one of the watersheds that contribute a large amount of soil loss in Lake Tana Basin. Like Gilgel Abay and Gumara watersheds, land use land cover was potentially changing the extent of soil erosion. And major area $(89.71 \%)$ of land in the Ribb watershed is cultivated land (Halefom et al. 2019b). Very sensitive areas are concentrated mainly in the upper and saturated bottomland part of the watershed land (Halefom et al. 2019b). It is likely due to gully initiation at the saturated bottom land and rill and sheet erosion by quick overland flow at the upside part. Stream power index is significant parameter to identify gully erosion vulnerability of the watershed. Many researchers conducted on role of stream power index on susceptibility of gully erosion (Jetten et al. 2003; Lulseged and Vlek 2005; Zegeye et al. 2016). The higher stream power index (SPI) with in the range of 6.1-8 in the field was identified as areas that have linked up with stream channels. Based on this truth gully potential areas other than the natural stream channels are areas with stream power index from 2 to 6 (Estifanos 2014). In rib watershed, $7.4 \%$ of the sub-watershed is gully potential areas where as only $2 \%$ of the watershed is potentially susceptible to gully erosion risk (Mhiret et al. 2019). Based on soil erosion susceptible classification, saturated bottomland is significantly potential to gully erosion, whereas upland part of the catchment is sensitive to sheet and rill erosion due to quick overland flow generation (Abiy 2009; Tebebu et al. 2010; Zegeye et al. 2016).

\section{Land use/cover change and hydrological condition of Megech catchment}

Land use classification map of Megech watershed shows $47 \%$ of land was erosion potential area which is covered with cultivated and bare land whereas only $3 \%$ of land was covered with dense forest where soil erosion is low in 2018 (Balabathina et al. 2019). In Megech watershed, 75\% of land was SPI in range of 2-13 which is most powerful to gully erosion (Balabathina et al. 2019). SPI will increase with increasing area and steepness of the catchment. Major area of Megech watershed is steep than other Lake Tana sub-basin. $52.2 \%$ of land is slope greater than $10 \%$ which is quick runoff is generated. Total amount of soil loss accounts in the catchment of Megech River with an average soil erosion rate of 41.54 ton $\mathrm{ha}^{-1} \mathrm{yr}^{-1}$. Estifanos (2014) estimated the average rate of soil loss as 39.8 ton $\mathrm{ha}^{-1} \mathrm{yr}^{-1}$ in the Ribb watershed that is adjacent to the Megech watershed. Sever soil erosion was occurred at the upper hilly and mountainous catchment of the watershed, particularly along the main streams and downslopes, It is may be due to gully and rill initiation.

\section{Research gap}

Many studies on soil erosion factor are carried out. Most studies conclude that land use/cover have significant potential to soil erosion. Inappropriate cultivated land use is the major source of soil erosion. Most of researches assessed the land use land cover change to investigate soil erosion hotspot area. It is due to land use/cover have the main factor affecting soil erosion. Various studies result on LULC 
change and its impact on basin hydrology have no clear and common conclusion. It is likely due to map generated from satellite image have some sort of error originated from various source such as method of image acquisition and classification. As a result, post classification refinement is needed to improve classification accuracy and reduce errors such as visual interpretation of unclassified satellite image, farmers' memory of land use history and several ground control points consisting of different LULC features and their location points collected will increase level of accuracy of image classification. In addition, intensive researches about root cause of soil erosion and to design appropriate control method are not clearly known.

\section{Conclusion}

Soil erosion is the major threat in Lake Tana Basin. Sediment transported to the lake is not only reducing the agricultural productivity but also disrupt lake's biodiversity due to reduce reservoir capacity and presence of eutrophication. Cultivated land is the major kind of land use which is the main factor contributed to soil erosion. It is due to quick runoff generation from agricultural land next to bare land. Even though, significant difference was observed between research findings on land use/cover change, many studies were conducted on impact of land use/cover change on soil erosion. Huge areas of land were changed to cultivate and settlement land from forest, grass and bush and shrub land. It was due to significance increase in population growth and to secure their livelihood. Improper cultivated land use with steep slope was the aggravating soil erosion in the Lake Tana Basin. To save the lake and basin biodiversity, different stakeholders such as government and environmental management NGOs should design appropriate type of land use and other source of income to ensure population livelihood. It helps to reduce expansion rate of land, exposed to inappropriate cultivated land use which is significant for accelerating soil erosion.

Funding This review paper is not funded.

\section{Compliance with ethical standards}

Conflict of interest The author declares that he have no conflicts of interest.

Open Access This article is licensed under a Creative Commons Attribution 4.0 International License, which permits use, sharing, adaptation, distribution and reproduction in any medium or format, as long as you give appropriate credit to the original author(s) and the source, provide a link to the Creative Commons licence, and indicate if changes were made. The images or other third party material in this article are included in the article's Creative Commons licence, unless indicated otherwise in a credit line to the material. If material is not included in the article's Creative Commons licence and your intended use is not permitted by statutory regulation or exceeds the permitted use, you will need to obtain permission directly from the copyright holder. To view a copy of this licence, visit http://creativecommons.org/licenses/by/4.0/.

\section{References}

Abebe WB, Minale AS (2017) Land use and watershed management practices in Lake Tana. In: Basin social and ecological system dynamics. Springer, Cham, pp 479-521

Abiy AZ (2009) Geological controls in the formations and expansions of Gullies over hillslope hydrological processes in the highlands of Ethiopia, Northern Blue Nile Region. Cornell University, New York

Andréassian V, Oddos A, Michel C, Anctil F, Perrin C, Loumagne C (2004) Impact of spatial aggregation of inputs and parameters on the efficiency of rainfall-runoff models: a theoretical study using chimera watersheds. Water Resour Res 40(5):1-9

Ayalew M., Angelidis T. (2019) Evaluate the impacts of land use/ land cover dynamics on stream flow of Gelda Watershed, Upper Blue Nile Basin, Ethiopia. Land cover dynamics on stream flow of Gelda Watershed, Upper Blue Nile Basin, Ethiopia (May 31, 2019)

Balabathina V, Raju R, Mulualem W (2019) Integrated remote sensing and GIS-based universal soil loss equation for soil erosion estimation in the Megech River Catchment, Tana Lake Sub-basin, Northwestern Ethiopia. Am J Geogr Inform Syst 8(4):141-157

Bosch JM, Hewlett J (1982) A review of catchment experiments to determine the effect of vegetation changes on water yield and evapotranspiration. J Hydrol 55(1-4):3-23

Butt A, Shabbir R, Ahmad SS, Aziz N (2015) Land use change mapping and analysis using remote sensing and GIS: a case study of simly watershed, Islamabad, Pakistan. Egypt J Remote Sensing Space Sci 18(2):251-259

Chakilu G, Moges M (2017) Assessing the land use/cover dynamics and its impact on the low flow of Gumara Watershed, Upper Blue Nile Basin, Ethiopia. Hydrol Curr Res 7(268):2

Cosandey C, Andréassian V, Martin C, Didon-Lescot J-F, Lavabre J, Folton N, Mathys N, Richard D (2005) The hydrological impact of the Mediterranean forest: a review of French research. J Hydrol 301(1-4):235-249

Derib SD, Assefa T, Berhanu B, Zeleke G (2009) Impacts of microbasin water harvesting structures in improving vegetative cover in degraded hillslope areas of north-east Ethiopia. Rangel $\mathbf{J}$ 31(2):259-265

Easton Z, Fuka D, White E, Collick A, Ashagre B, McCartney M, Awulachew S, Ahmed A, Steenhuis T (2010) A multi basin SWAT model analysis of runoff and sedimentation in the Blue Nile, Ethiopia. Hydrol Earth Syst Sci 14(10):1827-1841

Estifanos A (2014) Assessment of micro-watershed vulnerability for soil erosion in Ribb watershed using GIS and remote sensing. Mekelle University, Ethiopia

Fohrer N, Haverkamp S, Eckhardt K, Frede H-G (2001) Hydrologic response to land use changes on the catchment scale. Phys Chem Earth Part B: Hydrol Oceans Atmos 26(7-8):577-582

Guillemette F, Plamondon AP, Prévost M, Lévesque D (2005) Rainfall generated stormflow response to clearcutting a boreal forest: peak flow comparison with 50 world-wide basin studies. J Hydrol 302(1-4):137-153 
Halefom A, Teshome A, Sisay E (2019a) GIS-Based MCDA model to assess erosion Sensitivity in Gumara watershed, Blue Nile, Basin Ethiopia. Sciences 12(2):61-70

Halefom A, Teshome A, Sisay E, Dananto M (2019b) Erosion sensitivity mapping using GIS and multi-criteria decision approach in Ribb Watershed Upper Blue Nile, Ethiopia. Int J Energy Environ Sci 3(6):99

Huang Q-H, Zhang W-C (2004) Improvement and application of GISbased distributed SWAT hydrological modeling on high altitude, cold, semi-arid catchment of Heihe River Basin, China. p. 2

Hurni H (1983) Soil erosion and soil formation in agricultural ecosystems: Ethiopia and Northern Thailand. Mt Res Dev 3:131-142

Hurni H (1985a) An ecosystem approach to soil conservation. In: ElSwaify SA, Moldenhauer WC (eds) Soil erosion and conservation. Ankeny, USA: Soil Conservation Society of America, pp 759-771

Hurni H. (1985b) Erosion-productivity-conservation systems in Ethiopia. In: IV International Conference on Soil Conservation. Soil Conservation and Productivity: Proceedings, Maracay, Venezuela, 3-9 Nov 1985

Iroumé A, Huber A, Schulz K (2005) Summer flows in experimental catchments with different forest covers, Chile. J Hydrol 300(1-4):300-313

Jetten V, Govers G, Hessel R (2003) Erosion models: quality of spatial predictions. Hydrol Process 17(5):887-900

Lal R (1984) Soil erosion from tropical arable lands and its control. Adv Agron 37:183-248 Elsevier

Laurance WF (1998) A crisis in the making: responses of Amazonian forests to land use and climate change. Trends Ecol Evol 13(10):411-415

Lavabre J, Torres S, Cernesson F (1993) Changes in the hydrological response of a small Mediterranean basin a year after a wildfire. J Hydrol (Amsterdam) 142(1):273-299

Lulseged T, Vlek P (2005) GIS-based landscape characterization to assess soil erosion and its delivery potential in the highlands of northern Ethiopia. In: Proceedings of the 1st International Conference on Remote Sensing and Geo information processing in the assessment and monitoring of land degradation and desertification. pp 7-9

Mekonnen M, Melesse AM (2011) Soil erosion mapping and hotspot area identification using GIS and remote sensing in northwest Ethiopian highlands, near Lake Tana. In: Nile River Basin. Springer, Dordrecht, pp 207-224

Mhiret DA, Dagnew DC, Assefa TT, Tilahun SA, Zaitchik BF, Steenhuis TS (2019) Erosion hotspot identification in the sub-humid Ethiopian highlands. Ecohydrol Hydrobiol 19(1):146-154

Minale AS (2013) Retrospective analysis of land cover and use dynamics in Gilgel Abbay Watershed by using GIS and remote sensing techniques, Northwestern Ethiopia. Int J Geosci 4(07):1003

Moges DM, Bhat HG (2018) An insight into land use and land cover changes and their impacts in Rib watershed, north-western highland Ethiopia. Land Degrad Dev 29(10):3317-3330

Morgan R, Erosion CS (2005) Conservation. Blackwell Publishing, MA

Renard KG (1997) Predicting soil erosion by water: a guide to conservation planning with the Revised Universal Soil Loss Equation (RUSLE). United States Government Printing

Richey JE, Nobre C, Deser C (1989) Amazon River discharge and climate variability: 1903-1985. Science 246(4926):101-103
Rientjes T, Haile A, Kebede E, Mannaerts C, Habib E, Steenhuis T (2011) Changes in land cover, rainfall and stream flow in Upper Gilgel Abbay catchment, Blue Nile basin-Ethiopia. Hydrol Earth Syst Sci 15(6):1979-1989

Schulze R (2000) Transcending scales of space and time in impact studies of climate and climate change on agrohydrological responses. Agric Ecosys Environ 82(1-3):185-212

Setegn SG (2010) Modelling hydrological and hydrodynamic processes in Lake Tana Basin, Ethiopia. KTH

Setegn SG, Srinivasan R, Dargahi B (2008) Hydrological modelling in the Lake Tana Basin, Ethiopia using SWAT model. Open Hydrol J 2(1):49-62

Setegn SG, Srinivasan R, Dargahi B, Melesse AM (2009) Spatial delineation of soil erosion vulnerability in the Lake Tana Basin, Ethiopia. Hydrol Process Int J 23(26):3738-3750

Steenhuis TS, Collick AS, Easton ZM, Leggesse ES, Bayabil HK, White ED, Awulachew SB, Adgo E, Ahmed AA (2009) Predicting discharge and sediment for the Abay (Blue Nile) with a simple model. Hydrol Process Int J 23(26):3728-3737

Tebebu T, Abiy A, Zegeye A, Dahlke H, Easton Z, Tilahun S, Collick A, Kidnau S, Moges S, Dadgari F (2010) Surface and subsurface flow effect on permanent gully formation and upland erosion near Lake Tana in the northern highlands of Ethiopia. Hydrol Earth Syst Sci 14(11):2207-2217

Troendle CA, King RM (1987) The effect of partial and clearcutting on streamflow at Deadhorse Creek, Colorado. J Hydrol 90(1-2):145-157

Tu J (2009) Combined impact of climate and land use changes on streamflow and water quality in eastern Massachusetts, USA. J Hydrol 379(3-4):268-283

van Roosmalen L, Sonnenborg TO, Jensen KH (2009) Impact of climate and land use change on the hydrology of a large-scale agricultural catchment. Water Resour Res 45(7):W00A15. https://doi. org/10.1029/2007WR006760

Wischmeier WH, Smith DD (1978) Predicting rainfall erosion losses: a guide to conservation planning. Department of Agriculture, Science and Education Administration, Beltsville, MD

Wubie MA, Assen M, Nicolau MD (2016) Patterns, causes and consequences of land use/cover dynamics in the Gumara watershed of lake Tana Basin, Northwestern Ethiopia. Environ Syst Res 5(1):8

Yitaferu B (2007) Land degradation and options for sustainable land management in the Lake Tana Basin (LTB), Amhara Region. University of Bern, Ethiopia

Zegeye AD, Langendoen EJ, Stoof CR, Tilahun SA, Dagnew DC, Zimale FA, Guzman CD, Steenhuis TS (2016) Morphological dynamics of gully systems in the subhumid Ethiopian Highlands: the Debre Mawi watershed. Soil 2(3):443

Zhang L, Dawes W, Walker G (2001) Response of mean annual evapotranspiration to vegetation changes at catchment scale. Water Resour Res 37(3):701-708

Publisher's note Springer Nature remains neutral with regard to jurisdictional claims in published maps and institutional affiliations. 